\title{
○西尾綾子 ${ }^{1)}$ 、野口佳裕 ${ }^{1)}$ 、高木 明 $^{2)}$ 、喜多村 健 $^{1)}$ \\ 1) 東京医科歯科大学 医学部 耳鼻咽喉科、 \\ 2）静岡県立総合病院 頭頸部・耳鼻いんこう科
}

\section{【はじめに】}

非症候群性常染色体優性遺伝性難聴（DFNA）では、劣性遺伝性難聴におけるGJB2 や SLC26A4 など、比較的高頻度に認められる難聴遺伝子が同定されていない。そのためWFS 1 変異のように聴力型に特徵のある例を除き、変異同定率が必ずしも高くないのが実状と考 えられる。一方、遺伝子変異の創始者効果に着目し東アジア人に同定された既知の変異をス クリーニングすれば、効率よく遺伝子変異を同定できる可能性がある。

DFNA5 を原因遺伝子とする DFNA5 はこれまでに 5 家系の報告があり、その中の 3 家系 は東アジア人家系（中国 2 家系、韓国 1 家系）である。今回、我々は当施設の優性遺伝性家 系を対象に東アジア人に認められたDFNA5 変異の遺伝学的検査を施行した。

\section{【対象と方法】}

当施設耳鼻咽喉科外来受診患者において、優性遺伝形式の家族性難聴を示し文書による同 意と研究協力が得られた 96 家系の発端者を対象とした。中国と韓国の家系にて同定された 2つの DFNA5 変異 (c.991-15_991-13del、c.1183+4A>G) を含む領域を PCR にて増幅した。 オートシークエンサーにより塩基配列を決定し、変異の有無を検索した。変異が同定された 場合には、DFNA5 の全ての翻訳領域とエキソン・イントロン境界における変異の有無と家 系内における遺伝学的検査を行った。正常聴力者 90 例をコントロールとした。変異症例に 対しては、難聴の発症時期・進行やめまいの有無、オージオグラムの特徴、平衡機能検査所 見について検討した。

\section{【結果】}

欠失変異（c.991-15_991-13del）を96 例中 2例（2\%）に認めたが、c.1183+4A>G は同定 されなかった。正常コントロール 90 例には、これらの変異は認められなかった。欠失変異 を認めた 2 例では他の DFNA5 領域に変異を認めなかった。

変異家系 TMDU244（図 1）は 5 世代 35 人の家系で、12 例に純音聴力検査、遺伝学的検 査を施行した。聴力正常もしくは年齢相応と考えられる 4 例中 3 例は変異を認めなかった が、1例（V:10、22 歳女性）に変異が同定された。一方、難聴の 8 例すべてに変異を認め た。難聴者の難聴発症年齢は 10 歳から 30 歳であった。オージオグラムでは両高音障害型感 音難聴を示し、年齢とともに特に高音域の聴力䦐値が低下する傾向が認められた。また 4 周 波数平均聴力レベル（500、1000、2000、4000Hz）は、26.3dB から $103.8 \mathrm{~dB}$ であった。難聴 以外の全身合併症については、1例（V:8、18 歳男性）が初診から 2 年後に網膜色素変性症 を発症した。めまいの自覚がみられた例はなかったが、CCD 赤外線カメラにて 4 例中 2 例 に自発眼振を認めた。これらの 2 例に電気眼振検査を行った。1例（IV：7、52歳男性）に 頭位眼振検查において右下頭位で右向き水平性眼振を、1 例（V:7、20 歳男性）に頭位変換 
眼振検査で懸垂頭位から坐位の際に下眼瞼向き眼振を認めた。温度眼振検査では 2 例とも半 規管機能低下は認めなかった。

TMDU313（図 2）は 3 世代 12 人の家系で、発端者（III : 1、30 歳女性）のみに遺伝学的 検査を施行し、変異が同定された。難聴の発症年齢は 18 歳であり、難聴の進行を自覚して いた。オージオグラムでは両高音障害型感音難聴を示し、 4 周波数平均聴力レベルで右耳 61.3 $\mathrm{dB}$ 、左耳 $70.0 \mathrm{~dB}$ であった。めまいの自覚はなく眼振も認めなかった。側頭骨 CTでは内耳 奇形は認められず、難聴以外の全身合併症は認めなかった。

\section{【考察】}

DFNA5 変異は、オランダ、中国、韓国から 5 家系、4 種類の変異が報告されており、今 回の 2 家系は日本人として最初の DFNA5 家系と考えられた。 4 種類の変異はイントロン 7 もしくはイントロン 8 に認められ、翻訳の段階でエキソン 8 がスキップされるフレームシフ 卜変異と考えられている。

これまでの DFNA5 家系では、両側進行性の高音障害型感音難聴を認め、今回の家系でも 一致した結果を示した。難聴の発症時期は変異の種類により 10 歳未満から 40 代と幅広い が、c.991-15_991-13del を認めた過去の 2 家系では 10 歳未満から 20 代とされている。今回 TMDU244 の変異例 1 例では難聴は認められなかったが、今後難聴が発症する可能性がある と考えられた。平衡機能障害については、過去の報告では明記されたものはない。今回 TMDU 244 の変異例 2 例で自発眼振を認めたが、病歴聴取を行なった 4 例すべてにめまいの自覚は なく、温度眼振検査結果からも明らかな平衡機能障害はないものと考えられた。

図 1 (TMDU244)
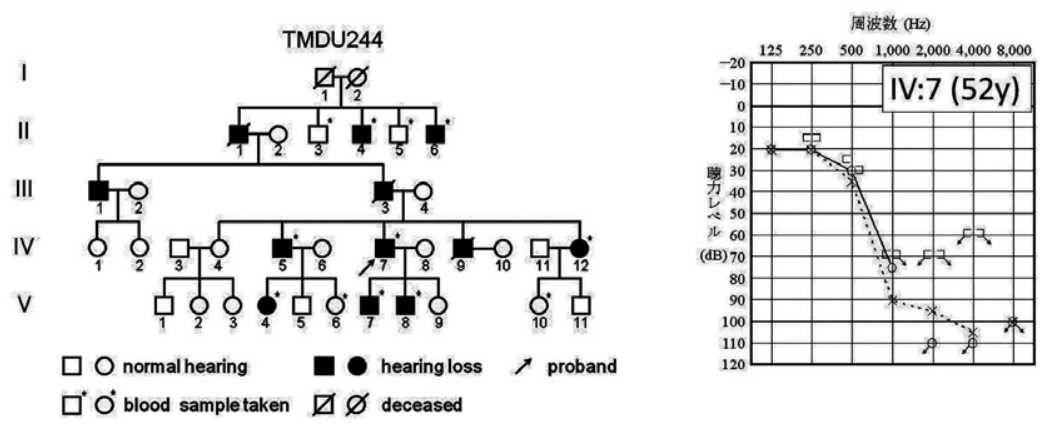

図 2 (TMDU313)
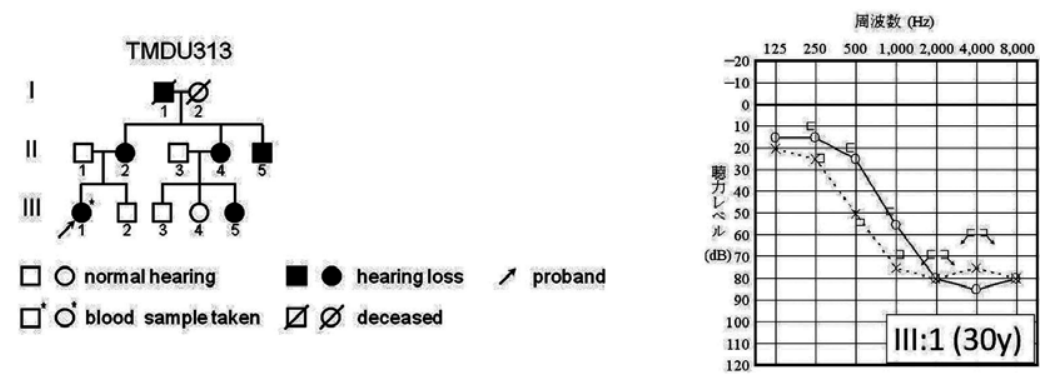